\title{
Chapter 10 \\ Migration of Ukrainian Nationals to Italy: Women on the Move
}

\author{
Francesca Alice Vianello
}

\subsection{Introduction}

Historically Italy has been a country of outward migration. Until the 1970s Italians emigrated to Northern Europe, the Americas and Australia (Monticelli 1967). The year that symbolizes the transformation of Italy from a country of emigration to one of immigration is 1981, when for the first time the census registered positive net migration. Following the oil crisis of 1973 Italian emigration reduced drastically and instead, inflows started to grow. This does not mean that immigration to Italy began because of the oil crisis. As noted by Colombo and Sciortino (2004), Italy was already a destination for some migratory movements, such as the seasonal immigration of Tunisian men in Sicily and female immigration from East Africa linked to Italy by its colonial past - and from the Philippines (Marchetti 2014).

In the 1980s and 1990s, Italy was an important destination for migrants from North Africa, especially from Morocco but also from Egypt, the former Yugoslavia and Albania. Finally, in the second half of the 1990s Italy became one of the most important destinations for Eastern European migrants: Romanians, Poles, Ukrainians and Moldovans.

This chapter describes the main characteristics of Ukrainian migration to Italy and the major studies of this migratory process, one which is characterized by the key role of middle-aged women. Ukrainian migration is contextualized within Italian migration as a whole and analyzed in terms of its main socio-demographic features: gender, age, education, entry route, participation in the Italian labour market and geographical settlement. The most detailed and interesting studies of

The original version of this chapter was revised. An erratum to this chapter can be found at DOI 10.1007/978-3-319-41776-9_14

F.A. Vianello $(\square)$

University of Padua, Padua, Italy

e-mail: francescaalice.vianello@unipd.it 
Ukrainian migration to Italy are also discussed. The majority of them are $\mathrm{PhD}$ theses investigating women's migratory trajectories, transnational motherhood, care chains, global families and migrants' incorporation in the domestic and care sector. Thereafter, the most typical profiles of Ukrainian migrant women living and working in Italy will be illustrated - "the migrant in transit" and "the permanent migrant" - in order to show the plurality of migration patterns and the role of structural constraints, but without losing sight of migrants' subjectivity. The chapter concludes with some considerations on future development of research on the Ukrainian presence in Italy.

\subsection{Facts and Figures of the Ukrainian Presence in Italy}

The most striking characteristic of immigration to Italy is its heterogeneity. The top three national groups currently are Romanians, Moroccans and Albanians, followed by Chinese, Ukrainians, Filipinos, Indians, Moldovans, Bangladeshis and Peruvians. These communities have different gender compositions. In one group - Moroccans, Albanians, Indians and Bangladeshis - there is a clear male preponderance. On the other hand there are migratory movements predominantly composed of women, such as Ukrainians, Filipinos and Moldovans. Finally, the Romanian and Chinese populations are gender balanced (see Table 10.1).

Since 1981, the number of foreign residents has increased from just over 200,000 to five million, a 25-fold increase. On 31 December 2014, the foreign population was 5,014,437 (Istat 2014a), that is, $8.3 \%$ of the total Italian population, a proportion that is similar to and in some cases even higher than that of traditional immigration countries, such as Germany, the UK and France. The number of foreign nationals has more than tripled compared to 2001. This increase is due both to new immigration and births, because the children of foreign citizens are recorded according to their parents' nationality.

Table 10.1 Resident foreign population in Italy by gender and citizenship, 31 December 2014 (Top ten national groups)

\begin{tabular}{l|l|l|l}
\hline & Male & Female & Total \\
\hline Romania & 487,203 & 644,636 & $1,131,839$ \\
\hline Albania & 254,622 & 235,861 & 490,483 \\
\hline Morocco & 243,052 & 206,006 & 449,058 \\
\hline China & 135,447 & 130,373 & 265,820 \\
\hline Ukraine & 47,393 & 178,667 & 226,060 \\
\hline Philippines & 733,320 & 94,918 & 168,238 \\
\hline India & 88,838 & 58,977 & 147,815 \\
\hline Republic of Moldova & 49,929 & 97,459 & 147,388 \\
\hline Bangladesh & 81,185 & 34,116 & 115,301 \\
\hline Peru & 45,653 & 64,015 & 109,668 \\
\hline
\end{tabular}

Source: Istat 2014a, http://demo.istat.it/str2014/index.html 




Fig. 10.1 Resident Ukrainian population on 1 January, time series Source: Istat 2015, http://dati. istat.it/Index.aspx?DataSetCode=DCIS_PERMSOGG1

Although contemporary Ukrainian migration to Italy started in the second half of the 1990s, it has only been statistically registered since the general immigration amnesty of 2002. Indeed, though in 2003 Istat (the Italian National Institute of Statistics) estimated that a mere 12,730 Ukrainian citizens were resident in Italy, by 2004 the number of Ukrainian residents had rapidly increased to 57,971 (see Fig. 10.1).

Since 2003 the number of Ukrainians living in Italy has increased year on year (Fig. 10.1), with some peaks coinciding with the regularization programmes implemented by Italy in 2009 and 2012 (Ambrosini 2013). As of 2015, 226,060 Ukrainian citizens are resident in Italy. They make up $6 \%$ of all non-EU citizens legally present in Italy, and are the fourth-largest national group. More than one million of the 3.8 million non-EU citizens come from the European continent. Ukrainians are the second-largest European community, after Albanians. However, from a sociodemographic point of view, the Albanian and Ukrainian communities are very different. Albanians began to arrive first, in the early 1990s, and their gender composition is slightly weighted in favour of men, with $54 \%$. Ukrainians, on the other hand, arrived later and their gender composition is strongly weighted the 


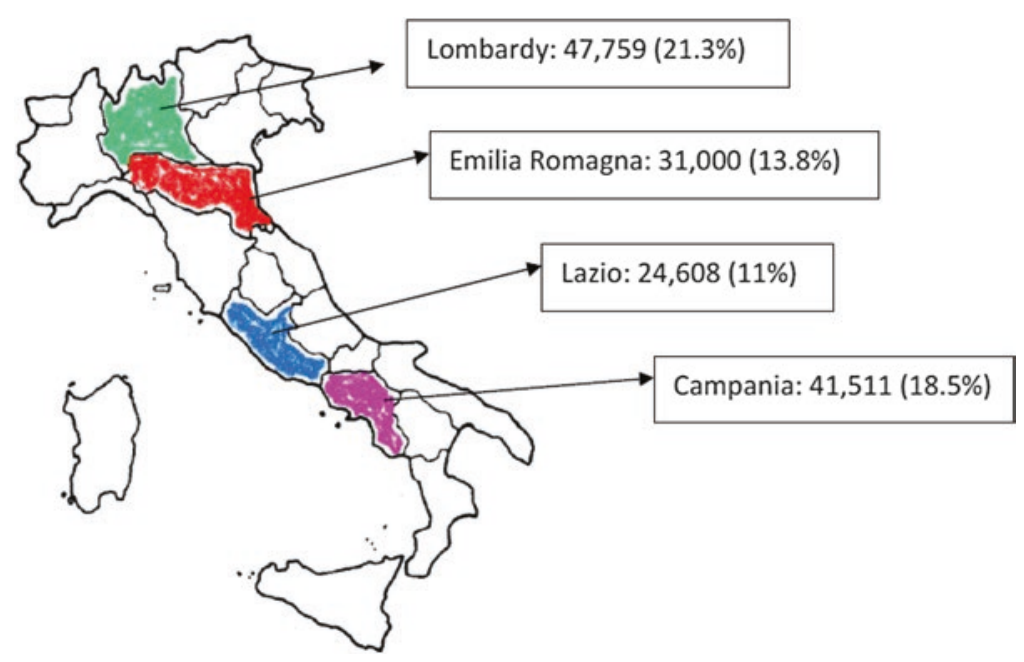

Map 10.1 Ukrainian settlement in four Italian regions (Source: Ministero del Lavoro e delle Politiche Sociali 2013)

opposite way, with $80 \%$ being women. Thus the first characteristic of the Ukrainian community is the strong prevalence of women.

The age composition is also noteworthy. The average age is 42.2 years, which is much higher than non-EU immigrants as a whole, whose average age is 31 . The largest age groups are 45-49 (11.7\% vs 8\% of non-EU immigrants), 50-54 (15.2\% vs $5.9 \%), 55-59(12 \%$ vs $3.8 \%)$ and 60 and over (11\% vs $4.9 \%)$. Furthermore, if we disaggregate these data by gender we can see that the women are, on average, older than the men. $40 \%$ of Ukrainian women are aged between 50 and 64, while $55 \%$ of Ukrainian men are under 34 (Ministero del Lavoro e delle Politiche Sociali 2013). Moreover, among the Ukrainians living in Italy, minors are only $9 \%$ of the total in contrast to $24.1 \%$ among the non-EU migrants as a whole. The majority of young Ukrainians living in Italy are adolescents attending high school (7996 students in the 2012/2013 school year) (Ministero del Lavoro e delle Politiche Sociali 2013). Thus, the second feature of the Ukrainian community in Italy is that it is chiefly composed of middle-aged women.

$52.9 \%$ of Ukrainians live in northern Italy, in particular in Lombardy (47,759 or $21.3 \%$ ) and in Emilia Romagna (31,000 or 13.8\%). However, there are also very significant settlements in central and southern Italy: 24,608 Ukrainians live in Lazio (11\%) and 41,511 in Campania (18.5\%). The cities with the highest concentration of Ukrainian citizens are: Naples (Campania), Milan (Lombardy), Rome (Lazio), Brescia (Lombardy) and Salerno (Campania). So the geographical distribution of Ukrainian settlement is the third feature of this migratory flow, since it is strongly concentrated in certain regions and in certain cities that are situated at opposite ends of the country, Lombardy in the north and Campania in the south (see Map 10.1) (Ministero del Lavoro e delle Politiche Sociali 2013). 
Levels of education among Ukrainian immigrants are quite high in comparison with other immigrants from non-EU European countries. $70 \%$ have at least secondary-level education, and $22 \%$ have also completed tertiary-level education, while only $12 \%$ of the other non-EU European immigrants have reached this level (Ministero del Lavoro e delle Politiche Sociali 2013).

The majority of Ukrainians hold a permit to stay for work reasons (almost 71\%), with family representing only $26.8 \%$ (Ministero del Lavoro e delle Politiche Sociali 2013). In 2013, 66.2\% of Ukrainian migrants of working age were employed, $13.1 \%$ were unemployed and $23.1 \%$ were inactive. In spite of the economic crisis, their unemployment rate was lower than the average of non-EU immigrants as a whole (18\%) (Direzione generale dell'Immigrazione e delle politiche di integrazione 2014). Their good performance in the labour market is due to the fact that the majority of Ukrainians are employed in the service sector, which has been less affected by the downturn than other economic sectors. Indeed, other national groups, such as Albanians and Moroccans, in which men employed in industry and construction predominate, have been the most affected by the downturn in jobs. In particular, in $2012,48.4 \%$ of Ukrainian workers (mostly women) were employed by Italian families as care workers or domestic workers, $7.3 \%$ were employed in the industrial sector, $6 \%$ in construction and $2 \%$ in agriculture (mostly men). However, despite their good performances, Ukrainian workers are badly paid: only $22 \%$ have a monthly income higher than $€ 1000$ (vs $45 \%$ for other non-EU European immigrants) and the majority of Ukrainians are in the €751-1000 income bracket. Therefore, another important characteristic of Ukrainian immigrants is that the majority of them are employed in the care and domestic sector and earn less than $€ 1000$ per month (Ministero del Lavoro e delle Politiche Sociali 2013) (for a discussion on the implications of gendered work sectors, see Chap. 5, and for a comparison with other countries with feminized migration, see Chap. 9).

\subsection{Literature and Research Overview}

The majority of the studies on Ukrainian immigration in Italy focus on female migration, given its gender composition. ${ }^{1}$ This migration attracted the interest of many scholars, who mainly analyzed the incorporation of the labour market, with particular relevance to care and domestic work (Spanò and Zaccaria 2003; Chiaretti 2004; Mingozzi 2005; Mazzacurati 2005). However, there are also some publications on return migration, new generations' migratory projects and the discourse on children left behind as a process of migrant women's stigmatization (Sacchetto 2011).

Furthermore, female Ukrainian migration has been the subject of a great number of doctoral theses written between 2008 and 2011 and then published in books and

\footnotetext{
${ }^{1}$ The only publication on male migration in Italy concerns the employment of Moldovan and Ukrainian migrants in the construction sector in Italy and in Russia (Morrison et al. 2013).
} 
scientific articles. Five dissertations by the following authors are of particular interest: Ludovica Banfi, Lena Näre, the present author, Cinzia Solari and Olena Fedyuk.

Ludovica Banfi in her dissertation (2008) ${ }^{2}$ compares the migration of different women, including Ukrainians, pointing out women's migratory projects, the impact of migration policies and incorporation in the workplace in Italy on transnational family life and the reorganization of the family in the face of the women's departure (Banfi 2009; Banfi and Boccagni 2011). Banfi underlines that even though the experience of transnational motherhood is shared by the majority of migrant women interviewed, such experiences are different according to the age of the mothers and children. Furthermore, she analyzes the family reorganization that occurs with the women's departure. She argues that Ukrainian families are already trained to deal with female migration, since during the Soviet period it was quite common for women to move away for study or work reasons, entrusting their children to grandmothers or other close female relatives.

Lena Näre's $\mathrm{PhD}$ thesis (2008) ${ }^{3}$ is based on an ethnographic research study conducted in Naples with three different national groups of domestic workers: Sri Lankan, Polish and Ukrainian (Näre 2009, 2011a, 2011b, 2013). In her work Näre stresses the negotiations and conflicts over gender/sexuality, 'race'/ethnicity, age and nationality taking place within the field of domestic work. In particular, she discusses the worker's role in the process of construction of the material, imaginary and social space of the employer's house, through the analysis of the meanings of everyday practices performed by maids and care workers, such as cooking, cleaning and caring.

My dissertation ${ }^{4}$ (2008) focuses exclusively on the migration of Ukrainian women to Italy, and investigates how migrant women move through the transnational space, mediating continuously between their own ambitions and external obligations, dictated both by structural processes, and by family and community social bonds (Vianello 2009; 2011, 2012, 2013b, 2013c; 2014b). I adopt the gender approach to the analysis of Ukrainian migration, showing the structural and family reasons for departure, the role of migrant social networks, work experience in the domestic and care sector and the impact of women migration on gender relations (see also Chap. 5).

Cinzia Solari's doctoral dissertation (2010a) ${ }^{5}$ compares two Ukrainian migratory movements: what she calls "the exile of older women to Italy" and "the exodus of entire families, led predominantly by older women, to California" (Solari 2006a, 2006b, 2010b; 2011). Solari analyzes several issues, such as: migrants' discourses

\footnotetext{
2 "Female migratory processes and family transnationalism". Originalh title: "Percorsi migratori femminili e transnazionalismo familiare".

3 "Managing households, making homes. A moral economy of migrant domestic and care workers in Naples".

${ }^{4}$ Francesca Alice Vianello "Migrating alone. Female practices of transnational mobility between Ukraine and Italy". Original title: "Migrando sole. Pratiche femminili di mobilità transnazionale tra Ucraina e Italia".

5 "Exile vs. Exodus: Nationalism and Gendered Migration from Ukraine to Italy and California".
} 
and practices with regard to their engagement in Ukrainian nation-building, the analysis of the post-Soviet transformations as a push factor for women emigration; the gender effects of post-Soviet migrations on Ukrainian society; migrant women's discourses and practices of gender identity negotiation at work; the different behaviour of the Greek Catholic Church and the Russian Orthodox Church toward Ukrainian immigrants in Italy (some of these issues are addressed further in Chap. 13).

Olena Fedyuk's PhD thesis (2011), ${ }^{6}$ is based on ethnographic field research among Ukrainian care and domestic workers living in Naples and Bologna. It explores how migrant women have translated the motherhood trope, giving meaning and legitimizing their migration in everyday practices, highlighting the negotiations, ruptures, coping mechanisms and continuities. To reach this objective she analyzes: the role of photographs in measuring time and maintaining connections between Ukraine and Italy; the reunification between migrants and their children; migrants' narratives of care work; and migrants' use of public spaces.

All these studies adopt the gender approach to frame Ukrainian migration, since it provides a useful instrument for the analysis of migratory patterns, the Italian labour market structure, Italian and Ukrainian care regimes and the implications of migration for power relations between men and women within families but also in the public sphere (Vianello 2013a; 2014a). Furthermore, they underline that Ukrainian immigration in Italy has to be contextualized in the processes of social and economic change that have affected both Italy and Ukraine in the last 30 years.

The political and economic transformations following the dissolution of the Soviet Union strongly affected Ukrainian women (see also Chap. 5). Migration became one of the most common solutions to cope with the tumultuous social and economic transformations occurring in Ukraine, but also one of the strategies adopted by Ukrainian women to pursue upward social mobility for their families.

In the 1990s and 2000s, the emergence of Ukrainian women's migration to Italy was matched by a demand for care and domestic workers resulting from the interplay of four social phenomena: the ageing of Italian society; the endurance in Italy of an unequal division of reproductive work according to gender; the Italian familist welfare state; and the growing participation of women in the workforce. The increase in female employment, which began in the 1970s, coincided neither with a more equal distribution of reproductive labour between men and women, nor with a transformation of the Italian welfare state. Women continued to be seen as the main caregivers of both children and elderly people, and the welfare state maintained its familistic structure, based on the male breadwinner model and characterized by cash transfers to households rather than the provision of services. As a consequence many women turned to private services to satisfy their families' care and domestic needs (Saraceno 2003; Zanfrini 2005; Bettio et al. 2006).

Italian families could rely on a cheap migrant labour force particularly suitable for working with elderly people full time, since they were white, Christian, middleaged and alone, hence without any family obligations. Indeed, Ukrainians are

\footnotetext{
6 "Beyond motherhood: Ukrainian female labour migrants to Italy".
} 
among the nationalities with the highest concentration in the care and domestic sector. After Filipino women, who have the highest degree of concentration in this sector $(72.5 \%)$ come Ukrainian women (64\%) (Direzione generale dell'immigrazione e delle politiche di integrazione 2012). Migrant workers therefore ensured the continuity of a care model centred on the family through the transfer of reproductive labour from the gift economy to the monetary economy (Bimbi 1999, 2014).

\subsection{The Migrant in Transit}

The migrant in transit is the most widespread type of Ukrainian immigrant. She is a middle-aged woman, often divorced or widowed (Vianello 2009), who left Ukraine when she was in her forties and her children were in their late teens or twenties. When she left her home country her plan was to stay abroad only for a year or two, with the aim of earning enough money to solve her economic problems at home and help her children to go to university and realize their potential. However her migratory experience in Italy goes on and on, for years, keeping her in a transitory condition or in a limbo in which she "put her life on hold until she returns to her family and will start a life again” as suggested by Fedyuk (2012: 297-298). She is strongly oriented to return, but she continuously postpones this event, carrying on living in Italy in precarious and marginal conditions (without a permit to stay; with a permit to stay but performing irregular work; working as live-in home care worker for many years).

Even if she stays in Italy for a long time (5-10 years), the narrations of the migrant in transit concerning her migratory project continue to identify return as her main goal. Thus, her behaviours, decisions, jobs, consumption and lifestyle are aimed at maximizing her earnings in order to return home soon, demonstrating loyalty to her family and fulfilling gender norms. She does not invest her energies in the improvement of her life and working conditions in Italy, since her life abroad is instrumental to the pursuit of her family interests, a realization that shapes her migratory experience. Indeed, according to Näre (2008), unlike Sri Lankan migrants, Ukrainian women do not invest in decorating their houses, since they perceive migration as a transitory moment in their life. They prefer to invest in decorating themselves or in status symbols to restore or improve their social identity.

The return is thus a myth situated at an undefined moment in the future, when the migrant in transit will have reached her economic goals, her children will be economically independent or the economic situation in Ukraine will have improved. Actually such conditions rarely come true. In particular, the Ukrainian economic and political situation has worsened year after year, despite the illusion of a visible improvement produced by the Orange Revolution (Solari 2006b). This is even more the case at this time with ongoing conflict, when the return is probably a mirage for many women. These migrants are thus in a situation of permanent instability, preventing them from either living fully in Italy or maintaining their social position in the origin country. 
From the professional point of view, the migrant in transit experiences a radical process of devaluation. Even if she is well educated, highly skilled and has work experience in the education, health or administrative sectors, when she arrives in Italy she finds only low-skilled and badly paid jobs in the domestic and care sector. Usually she accepts working for many years as live-in home help or carer of elderly people without looking for another job as many migrant women do, because this allows her to save money on accommodation and board. Furthermore, working in the domestic sphere permits her to live in the shadows and to reduce the risk of being stopped by Italian police, given that during the first years of her stay in Italy she is undocumented. ${ }^{7}$ The live-in work is characterized by an extremely heavy workload and potentially endless working days, because of the overlap between home and place of work. Furthermore, according to Näre (2007, 2011b) the labour contract is accompanied by a moral contract based on normative notions of familial duty, reciprocity and gratitude. It means that labour relationships are transformed by both employers and employee into family-like relationships due to the locus of the work within the domestic sphere and the highly personalized nature of care work. However, the migrant in transit accepts this job, because she sees the migratory experience as just an interlude in her life. It is a "short" period of time spent far from her home country, during which it is acceptable to occupy the lowest rungs of the social ladder. According to this view, downward mobility is more admissible since if it happens in a foreign country it does not radically impact migrants' social status (Vianello 2014a, b).

The migrant in transit identifies herself primarily as a mother, even if she has adult children and is often a grandmother (Marchetti and Venturini 2013), since she uses this social role to make sense of her migration and to legitimize her absence (Vianello 2009, 2011). Her narrations are permeated with the rhetoric of sacrifice: she is working abroad only to fulfil her "mission", that is guaranteeing the economic well-being of her family and in particular of her children, postponing her own wellbeing. Indeed, according to Fedyuk's analysis of the pictures that circulate between Ukrainian migrant mothers and their families left behind, a migrating woman has to be very cautious about selecting photographs to send home, since she has to be careful not to suggest that she has a new life abroad. The photographs should, instead, represent the migratory experience as a sacrifice and confirm the mother's devotion to family interests. For this reason photographs usually portray the migrant woman alone, stressing emotions of solitude and nostalgia (Fedyuk 2012).

The rhetorical discourse used by the migrant in transit to explain migration is based on the idea of the brave mother, real pillar of the family and society, contrasted to that of the weak man, an idler unable to fulfil his family duties (Vianello 2009). The rhetoric of female power could be partially explained as a mix of Soviet propaganda depicting mother-workers as heroes and the post-Soviet revival of the Berehynia myth, the ancient pagan goddess representing the "hearth mother" (see

\footnotetext{
${ }^{7}$ The majority of Ukrainian women arrived in Italy with a tourist visa that they overstayed. This means that they spend one or more years as irregular migrants. Usually they obtain a permit to stay through one of Italy's amnesty programmes (Ambrosini 2013).
} 
also Chap. 5). In both cases women are depicted as independent, powerful and family oriented, but while in the first case males are portrayed as weak, in the second case the patriarchal order is reaffirmed. The migrant in transit, according to the Soviet rhetoric, portrays herself as a heroine and her husband as a failure, but at the same time she ideologically endorses the Berehynia model. She uses this contradictory discourse to answer accusations of being a bad mother and a rebel wife, who is subverting the Ukrainian patriarchal gender order that is supported by many actors in the Ukrainian public sphere (Lutz and Palenga-Möllenbeck 2012).

The conflict between these two models is projected onto subsequent generations. Some migrants in transit seek to re-establish the gender order in the next generation, using remittances to enable their daughters to be proper mothers and wives, who stay at home with their children, and their sons to be proper men, independent and able to maintain their family (Solari 2010b; see also Chap. 5). Others seek a different future for their children, attempting to transmit to them an alternative gender model, not necessarily based on family roles (Vianello 2013a, b, c).

The migrant in transit is constrained by a dense network of obligations and pressures: maternal responsibilities, relatives' and community's expectations, Ukrainian economic and political instability and the suffocating job of home care worker. However, within this narrow horizon she finds spaces for agency and self-realization. Her migratory status offers her a powerful new personal and social identity. First of all, she exercises her power through the management of remittances, deciding how to spend money and who will benefit. She is aware of her economic power and proud of her capacity to improve the living conditions of her family left behind. This strengthens her self-esteem and enhances her social status (Vianello 2013b). Second, active participation in religious communities and ethnic associations is one of the most common practices adopted by the migrant in transit to seek fulfilment, validate her skills and distinguish herself during her stay in Italy. She devotes her free time to being leader of an ethnic association, minister of music in the church, Ukrainian language teacher in the community school for second-generation children, or journalist for small newspapers (Vianello 2014a, b). Finally, according to Fedyuk (2011), the migrant in transit does not completely renounce her romantic and sexual life. She establishes romantic and sexual relations with Italian men, without threatening her capacity to perform the idealized role of a sacrificing mother.

To conclude, the reasons why the migrant in transit's stay in Italy gets longer are multi-layered and include both economic and emotional reasons (Hochschild 2002). First of all, remittances become an indispensable income for her left-behind relatives, in particular when her children get married and have their own children. According to Banfi (2009) Ukrainian women maintain a strong "ethics of remittances" even several years after leaving. Money is destined for their children, who grow up with a high degree of dependence on remittances even after the conclusion of their education, probably because of the lack of professional opportunities in Ukraine. Second, the migrant's advanced age reduces her labour prospects in Ukraine and thus the possibility of being independent. Hence she chooses to finish her working life in Italy. She is also aware that she needs to put aside some money 
for her old age, given that Ukrainian pensions are very low. ${ }^{8}$ Third, after many years abroad (from five to ten), the migrant in transit starts to build her identity around the figure of migrant worker and she does not really want to change her status/position in society again. In other words she is afraid to return and prefers to carry on her transnational life, since it guarantees her economic independence and power. Thus, sometimes finding new economic needs for the family left behind is a strategy to justify the extension of migration and postpone the return.

\subsection{The Permanent Migrant}

The permanent migrant is a woman with a stronger, more individualistic attitude, who is not willing to sacrifice her life and to work as a live-in caregiver for a long period. Thus, she can be considered a "rebel woman", who finds a way to avoid social expectations and to undertake a new life in Italy, characterized in this case no longer by precariousness but by stability. Usually she is a little bit younger than the migrant in transit and her children are teenagers. She emigrated in her thirties in order to provide a better life for herself and her children and to escape from an unhappy marriage and/or an unsatisfying life in Ukraine (Vianello 2009).

During the early years of her stay in Italy her life and working conditions are very similar to those of the migrant in transit: undocumented and employed as livein domestic or care worker. However, when she obtains documents her trajectory differs significantly from the migrant in transit. She abandons her initial project of short-term migration and starts looking for another job that will allow her to live away from the workplace. She usually turns to working as an hourly home helper and shares an apartment with compatriots. These choices make her working days harder, since to earn enough money to pay her expenses and continue sending remittances home, she needs to work many hours a day and for many different families, going from one house to another (Näre 2008).

Having several employers and living with other women allows the permanent migrant to enlarge and enrich her social network: she starts to select her friends, to have Italian acquaintances, even if relations are hierarchical because they are often her employers, and to distance herself from Ukrainian community social spaces, such as the Greek Catholic or Orthodox churches and ethnic associations. However, the real shift in her social and working life takes place when she finds a job outside the domestic sphere, given that she can access a wider social network and a richer social capital through her new acquaintance with Italian people. Sometimes among these new acquaintances she meets an Italian man and starts to date him. ${ }^{9}$

\footnotetext{
${ }^{8}$ The monthly average pension is now 1573 grivna (about 62 euro) (State Statistic Committee of Ukraine 2015).

${ }^{9}$ In 2013 there were 14,383 marriages between an Italian man and a foreign woman. The most common nationalities of women were Romanian (19.2\%), Ukrainian (11\%) and Brazilian (6.2\%) (Istat 2014b).
} 
Regaining her freedom and social life is not enough for a full redefinition of the migratory project. If she is not reunited with her nuclear family and in particular with her children, she continues deeply linked to Ukraine. Thus, if she really wants to re-orient her life project and settle in Italy she needs to organize family reunification. When the permanent migrant is still married this is often the moment when divorce occurs. Nevertheless, there are also cases in which the husband accepts moving to Italy.

According to Fedyuk (2011), any analysis of family reunification practices has to consider both reunification with children under 18, provided for by Italian law, and reunification with children over 18 , which is arranged through other channels, such as buying a tourist visa or requesting an official workforce. In the first case, in accordance with Italian law, the permanent migrant has to fulfil income and housing requirements, while in the second case, she has to find a way to obtain a permit to stay for work or study. In both cases, great commitment from the migrant is needed to achieve the formal or informal reunification process (see also Chap. 5).

Fedyuk (2015) also points out that reunification after many years of separation does not always fulfil migrants' and children's expectations. Ukrainian teenagers can be disappointed by reunification since it changes them from the remittance bourgeoisie in Ukraine to migrant working class in Italy: even if they live with their mothers, they see little of them because they are working all day; they live in modest flats, sometimes shared with other people; they have little money to spend on their own amusement; and they realize that they do not have great opportunities for upward mobility in Italy. Furthermore, if they are not prepared to live in a multicultural society and to interact with other second-generation teenagers of different ethnic origins, they develop racist attitudes. For these reasons, many Ukrainian youths do not settle in Italy, but circulate between Ukraine and Italy. Some of them prefer to continue living in Ukraine, even if they maintain their permission to stay to visit their mothers. Others can be defined as cosmopolitans and after finishing their studies in Italy they develop transnational economic activities between Italy and Ukraine (Vianello 2013c).

To conclude, the permanent migrant is a woman who considers the option of settling in Italy, since she does not want to renounce her well-being completely. Her gaze is oriented towards the immigration country, where she wants to build a new life with her children and for this she is available to invest resources to improve her life abroad. The permanent migrant is, thus, a woman who, also due to her younger age, has risen above that dense network of social obligations and working conditions trapping the migrant in transit.

\subsection{Conclusions}

According to Morokvasic (2003), the post-Soviet transition has forced a great number of women to be on the move, circulating in a new migratory space and adopting different migration strategies from men. For many women, like the migrants in 
transit, migration has become a lifestyle. In a sense they depart in order to stay and carry on their family project.

At the moment the Ukrainian community in Italy is still composed mainly of this category of women. However, the profile of the Ukrainian nationals will probably change in the coming years. It is seeing an increase in the number of young people, male and female, and of men, because of family reunification carried out by permanent migrants. Furthermore, given the conflict that is taking place in Ukraine we can expect a growth in the rate of immigration of young men escaping from military service and putting down roots among the Ukrainian community in Italy. Hence, in the future it is likely that: (1) the average age will fall; (2) the gender composition will be more balanced; and (3) Ukrainian citizens will perform a wider variety of jobs, in particular those belonging to the second generation.

First, future studies on Ukrainians in Italy should therefore focus on the working trajectories of women and men of the first and second generations, since it enables an understanding of the level of segregation of Ukrainian immigrants in the Italian labour market and their social mobility patterns (see also the Conclusions section in Chap. 5). To do this kind of research both qualitative and quantitative data are necessary, such as representative and longitudinal surveys and biographical interviews.

Second, another significant issue still little studied is cross-national marriages between Ukrainian women and Italian men. By analyzing practices and discourses connected to them it is possible to investigate women's agency but also the processes of racialization and sexualization of Eastern European women. In relation to this matter, it would be very helpful to analyze the media representation of crossnational marriages, but also to conduct in-depth interviews and focus groups with wives, husbands and their relatives.

Third, it would be interesting to investigate the impact of the ongoing conflict on Ukrainian migrants' grassroots organizations and the narrations produced by associations and single migrants on these issues. Here the best methodology would be ethnography.

Finally, more research is needed on the ageing of those migrants in transit who in the end do not want to or cannot return to Ukraine. What happens to these women trapped in transnational space when they get older? More accurate information could be gained on these questions by involving not only elderly migrant women but also public social and health institutions.

\section{References}

Ambrosini, M. (2013). Irregular migration and invisible welfare. London: Palgrave Macmillan.

Banfi, L. (2008). Percorsi migratori femminili e transnazionalismo familiare. [Female migratory processes and family transnationalism]. Trento: Università di Trento.

Banfi, L. (2009). Genere e legami familiari transnazionali Gender and transnational family ties. In R. Catanzaro \& A. Colombo (Eds.), Badanti \& Co. Il lavoro domestico in Italia Badanti \& Co. The domestic work in Italy (pp. 195-218). Bologna: Il Mulino. 
Banfi, L., \& Boccagni, P. (2011). Transnational family life and female migration in Italy: One or multiple patterns? In A. Kraler, E. Kofman, M. Kohli, \& C. Schmoll (Eds.), Gender, generations and the family in international migration (pp. 285-310). Amsterdam: Amsterdam University Press.

Bettio, F., Simonazzi, A., \& Villa, P. (2006). Change in care regimes and female migration: The 'care drain' in the Mediterranean. Journal of European Social Policy, 16(3), 271-285. doi: $10.1177 / 0958928706065598$.

Bimbi, F. (1999). Measurement, quality, and social change in reproduction time. The twofold presence of women and the gift economy. In O. Hufton \& Y. Kravaritou (Eds.), Gender and the use of time/Gender and Emploi du Temps (pp. 151-171). The Hague: Kluwer Law International.

Bimbi, F. (2014). Symbolic violence: Reshaping post-patriarchal discourses on gender. In M. T. Segal \& V. Demos (Eds.), Gendered perspectives on conflict and violence: Part B (Advances in gender research, volume 18B, pp. 275-301). Bingley: Emerald Group Publishing Limited.

Chiaretti, G. (2004, ottobre-dicembre). A capo delle loro famiglie e a servizio delle nostre famiglie: i racconti di donne emigrate dall'Est-Europa At the head of their families and at the service of our families: Stories of women emigrated from eastern Europe. Inchiesta, 21-32.

Colombo, A., \& Sciortino, G. (2004). Italian immigration: The origins, nature and evolution of Italy's migratory systems. Journal of Modern Italian Studies, 9(1), 9-70.

Direzione generale dell'immigrazione e delle politiche di integrazione. (2012). Secondo rapporto annuale sul mercato del lavoro degli immigrati Second annual report on the immigrant labour market. Rome: Ministero del Lavoro e delle Politiche Sociali.

Direzione generale dell'immigrazione e delle politiche di integrazione. (2014). Quarto Rapporto annuale sul mercato del lavoro degli immigrati. Fourth annual report on the immigrant labour market.. Rome: Ministero del Lavoro e delle Politiche Sociali.

Fedyuk, O. (2011). Beyond motherhood: Ukrainian female labor migration to Italy. $\mathrm{PhD}$ dissertation submitted to the Central European University. http://www.etd.ceu.hu/2011/fedyuk_olena. pdf. Accessed 9 Sep 2015.

Fedyuk, O. (2012). Images of transnational motherhood: The role of photographs in measuring time and maintaining connections between Ukraine and Italy. Journal of Ethnic and Migration Studies, 38(2), 279-300. doi:10.1080/1369183X.2012.646422.

Fedyuk, O. (2015). Growing up with migration: Shifting roles and responsibilities within the transnational families of Ukrainian care-workers in Italy. In M. Kontos \& G. Tibe Bonifcacio (Eds.), In the dark: Family rights and migrant domestic work. Submitted for publication, under contract with Palgrave.

Hochschild, H. R. (2002). The sociology of emotions as a way of seeing. In G. Bendelow \& S. J. Williams (Eds.), Emotions in social life: Critical themes and contemporary issues (pp. 3-16). New York: Routledge.

Istat. (2014a). Cittadini Stranieri. Popolazione residente e bilancio demografico al 31 dicembre 2014 Italia. [Foreign citizens. Resident population and demografic balance on the 31th of December 2014, Italy]. http://demo.istat/str2014/index.html. Accessed 8 Sep 2015.

Istat. (2014b). Anno 2013: Il matrimonio in Italia. [Year 2013: Marriage in Italy]. http://www.istat. it/archivio/138266. Accessed 8 Sep 2015.

Lutz, H., \& Palenga-Möllenbeck, E. (2012). Care workers, care drain, and care chains: Reflections on care, migration, and citizenship. Social Policy, 19(1), 15-37. doi:10.1093/sp/jxr026.

Marchetti, S. (2014). Black girls. Migrant domestic work and colonial legacies. Boston: Brill.

Marchetti, S., \& Venturini, A. (2013). Mothers and grandmothers on the move: Labour mobility and household strategies of Moldovan and Ukrainian migrant women in Italy. International Migration, 52(5), 111-126.

Mazzacurati, C. (2005). Dal blat alla vendita del lavoro. Come sono cambiate colf e badanti ucraine e moldave a Padova. [From 'blat' to selling work. How Ukrainian and Moldovan care and domestic workers have changed in Padova]. In T. Caponio \& A. Colombo (Eds.), Migrazioni globali e integrazioni locali [Global migrations and local integrations] (pp. 145174). Bologna: Il Mulino. 
Mingozzi, A. (2005). Il lavoro domestico nel distretto faentino. Effetti di regolarizzazione sulle lavoratrici provenienti dall'ex Unione Sovietica. [Domestic work in the Faenza district. Effects of the regularization on workers from the former Soviet Union] In T. Caponio, \& A. Colombo (Eds.), Migrazioni globali e integrazioni locali [Global migrations and local integrations] (pp. 117-144). Bologna: Il Mulino.

Ministero del Lavoro e delle Politiche Sociali. (2013). La Comunità Ucraina in Italia. [Ukrainian community in Italy]. www.integrazionemigranti.gov.it. Accessed 8 Sep 2015.

Monticelli, G. L. (1967). Italian emigration: Basic characteristic and trends with special reference to the last twenty years. International Migration Review, 1(3), 10-24.

Morokvasic, M. (2003). Transnational mobility and gender: A view from post-wall Europe. In M. Morokvasic, U. Erel, \& K. Shinozaki (Eds.), Crossing borders and shifting bounderies (Gender on the move. Vol. II, pp. 137-154). Opladen: Leske \& Budrich.

Morrison, C., Sacchetto, D., \& Cretu, O. (2013). International migration and labour turnover: Workers' agency in the construction sector of Russia and Italy. Studies of Transition States and Societies, 5(2), 7-20.

Näre, L. (2008). Managing households, making homes. A moral economy of migrant domestic and care workers in Naples. University of Sussex. http://dare.uva.nl/cgi/arno/show.cgi?fid=199989. Accessed 9 Sep 2015.

Näre, L. (2009). The making of 'Proper' homes - Everyday practices of migrant domestic work in naples. Modern Italy, 14(1), 1-17. doi:10.1080/13532940802535408.

Näre, L. (2011a). The informal economy of paid domestic work - The case of Ukrainian and Polish migrants in Naples. In M. Bommes \& G. Sciortino (Eds.), Foggy social structures: Irregular migration and informal economy in western europe (pp. 67-87). Amsterdam: Amsterdam University Press.

Näre, L. (2011b). The moral economy of paid domestic and care work: Migrant workers in naples, Italy. Sociology, 45(3), 396-412. doi:10.1177/0038038511399626.

Näre, L. (2013). Migrancy, gender and social class in domestic labour and social care in Italy: An intersectional analysis of demand. Journal of Ethnic and Migration Studies, 39(4), 601-623. doi:10.1080/1369183X.2013.745238.

Sacchetto, D. (Ed.). (2011). Ai margini dell'Unione Europea. Spostamenti e insediamenti a Oriente. [At the margins of the European Union. Movements and settlements to the East]. Roma: Carocci.

Saraceno, C. (2003). Mutamenti della famiglia e politiche sociali in Italia. Bologna: Il Mulino.

Solari, C. (2006a). Professionals and saints: How immigrant careworkers negotiate gendered identities at work. Gender \& Society, 20, 301-331. doi:10.1177/0891243205285633.

Solari, C. (2006b). Transnational politics and settlement practices: Post-soviet immigrant churches in Rome. American Behavioral Scientist, 49, 1528-1553. doi:10.1177/0002764206288848.

Solari, C. (2010a). Exile vs. Exodus: Nationalism and gendered migration from Ukraine to Italy and California. University of California. https://www.escholarship.org/uc/item/2zc4v198. Accessed 9 Sep 2015.

Solari, C. (2010b). Resource drain vs. Constitutive circularity: Comparing the gendered effects of Post-Soviet migration patterns in Ukraine. Anthropology of East Europe Review, 28, 215-238.

Solari, C. (2011). Between "Europe" and "Africa": Building the new Ukraine on the shoulders of migrant women. In M. J. Rubchak (Ed.), Mapping difference: The many faces of women in Ukraine (pp. 23-40). New York: Berghahn Books.

Spanò, A., \& Zaccaria, A. M. (2003). Il mercato delle collaboratrici domestiche a Napoli: il caso delle ucraine e delle polacche [The market of domestic workers in Naples: The case of Ukrainians and Poles]. In M. La Rosa \& L. Zanfrini (Eds.), Percorsi migratori tra reti etniche, istituzioni e mercato del lavoro [Migratory trajectories: Ethnic networks, institutions and labour market] (pp. 193-224). Milano: Franco Angeli.

State Statistic Committee of Ukraine. (2015). Monthly average pensions and amount of pensioner. http://ukrstat.org/en/operativ/operativ2007/sz/sz_e/srp_07rik_e.html. Accessed 9 Sep 2015. 
Venturini, A., \& Marchetti, S. (2013). Mothers and grandmothers on the move: Labour mobility and household strategies of Moldovan and Ukrainian migrant women in Italy. International Migration, 52(5), 111-126. doi:10.1111/imig.12131.

Vianello, F. A. (2008). Migrando sole. Pratiche femminili di mobilità transnazionale tra Ucraina e Italia. [Migrating alone. Female practices of transnational mobility between Ukraine and Italy.] Padova: Università di Padova.

Vianello, F. A. (2009). Migrando sole. Legami transnazionali tra Ucraina e Italia. [Migrating alone. Transnational ties between Ukraine and Italy]. Milano: Franco Angeli.

Vianello, F. A. (2011). Suspended migrants. Return migration to Ukraine. In M. Nowak \& M. Nowosielski (Eds.), (Post)trans-formational migration (pp. 251-274). Berlin: Peter Lang.

Vianello, F. A. (2012). Continuità e confini tra vita pubblica e vita privata. La doppia presenza delle assistenti familiari. [Continuity and boundaries between public and private life. The double presence of the family assistants]. AG About Gender, 1(2), 175-203.

Vianello, F. A. (2013a). Engendering migration. Un percorso attraverso trent'anni di dibattito. Mondi Migranti, 3, 49-66. doi:10.3280/MM2013-003003.

Vianello, F. A. (2013b). Ukrainian migrant women's social remittances: Contents and effects on families left behind. Migration Letters, 10(1), 91-100.

Vianello, F. A. (2013c). A transnational double presence: Circular migrations between Ukraine and Italy. In A. Triandafyllidou (Ed.), Circular migration between Europe and its neighbourhood. Choice or necessity? (pp. 187-211). Oxford: Oxford University Press.

Vianello, F. A. (2014a). Genere e migrazioni. Prospettive di studio e di ricerca. Milano: Guerini.

Vianello, F. A. (2014b). Ukrainian migrant workers in Italy: Coping with and reacting to downward mobility. Central and Eastern European Migration Review (CEEMR), 3(1), 85-98.

Zanfrini, L. (2005). La rivoluzione incompiuta. Roma: Edizioni Lavoro.

Open Access This chapter is distributed under the terms of the Creative Commons AttributionNoncommercial 2.5 License (http://creativecommons.org/licenses/by-nc/2.5/) which permits any noncommercial use, distribution, and reproduction in any medium, provided the original author(s) and source are credited.

The images or other third party material in this chapter are included in the work's Creative Commons license, unless indicated otherwise in the credit line; if such material is not included in the work's Creative Commons license and the respective action is not permitted by statutory regulation, users will need to obtain permission from the license holder to duplicate, adapt or reproduce the material. 